\title{
PELATIHAN PEMBUATAN POT LUKIS SEBAGAI MEDIA SOSIALISASI KURANGI PLASTIK DI SEKOLAH PAKET UPT PASAR SUKATANI DEPOK
}

\author{
Yuni Zaharani ${ }^{1}$, Martha Tisna Ginanjar Putri ${ }^{2}$, Enny Nurcahyawati ${ }^{3}$ \\ Program Studi Desain Komunikasi Visual Fakultas Bahasa dan Seni, Universitas Indraprasta PGRI
}

\begin{abstract}
Abstrak
Indonesia merupakan salah satu penyumbang terbesar sampah plastik ke lautan berdasarkan hasil penelitian Dr. Jenna Jambeck dari Universitas Georgia (Jurnal Science, www.sciencemag.org, 2015). Berbagai upaya pemerintah mengurangi sampah plastik tidak akan berhasil tanpa adanya peran aktif seluruh komponen masyarakat. Tim abdimas Universitas Indraprasta PGRI berupaya memberikan solusi melalui pelatihan pembuatan kriya pot lukis dari botol plastik bekas. Pelatihan dilaksanakan di Sekolah Paket B dan C UPT Pasar Sukatani Depok. Tujuan dari kegiatan pengabdian masyarakat ini adalah meningkatkan kesadaran peserta didik Sekolah Paket B dan C UPT Pasar Sukatani Depok, khususnya dan masyarakat luas umumnya akan pentingnya mengurangi sampah plastik mengingat bahaya sampah plastik yang begitu besar. Pelatihan ini juga bertujuan membantu program pemerintah dalam upaya mengurangi jumlah sampah plastik yang ada di Indonesia. Metode penelitian yang digunakan adalah metode kualitatif yaitu dengan mengumpulkan data berupa survei ke lokasi mitra, wawancara, dan pelatihan. Hasil dari pengabdian masyarakat ini adalah pot lukis dari botol plastik bekas yang dapat digunakan sebagai media sosialisasi kurangi sampah plastik di Sekolah Paket B Dan C UPT Pasar Sukatani Depok
\end{abstract}

Kata Kunci : pot lukis, sampah plastik, sosialisasi

\begin{abstract}
Indonesia is one of the biggest contributors to plastic waste to the ocean based on the results of Dr. Jenna Jambeck from the University of Georgia (Journal of Science, www.sciencemag.org, 2015). Various government efforts to reduce plastic waste will not succeed without the active role of all components of the community. The team from the Indraprasta University PGRI team tried to provide a solution through training in making craft pots made from used plastic bottles. The training was held at the Paket B and C Schools of the Sukatani Market, Depok. The aim of this community service activity is to increase the awareness of students of the Paket B and C Schools of the UPT Market Sukatani Depok, in particular and the wider community in general about the importance of reducing plastic waste given the enormous danger of plastic waste. The training also aims to assist government programs in efforts to reduce the amount of plastic waste in Indonesia. The research method used is a qualitative method by collecting data in the form of surveys to partner locations, interviews, and training. The results of this study are painting pots from used plastic bottles that can be used as a media campaign to reduce plastic waste in the $B$ and C School Package at UPT Pasar Sukatani Depok.
\end{abstract}

Keywords: painting pot, plastic waste, socialization

Correspondence author: Yuni Zaharani, yuniizaharanii@gmail.com, Jakarta, Indonesia

This work is licensed under a CC-BY-NC 


\section{PENDAHULUAN}

Indonesia berada di peringkat kedua dari 192 negara sebagai penyumbang sampah plastik terbesar ke lautan berdasarkan hasil penelitian Dr. Jenna Jambeck dari Universitas Georgia yang dipublikasikan dalam Jurnal Science (www.sciencemag.org) pada 12 Februari 2015. Indonesia masuk dalam 5 besar penyumbang sampah plastik terbesar ke lautan dengan urutan Tiongkok, Indonesia, Filipina, Vietnam dan Srilanka. Data tersebut membuktikan bahwa belum adanya pengelolaan sampah yang baik di Indonesia, sehingga laut ikut terdampak oleh adanya sampah plastik.

Tingginya jumlah sampah plastik di Indonesia disebabkan oleh belum adanya pengelolaan sampah yang baik, rendahnya kesadaran masyarakat akan bahaya sampah, dan kurangnya tanggung jawab produsen produk plastik yang hanya berorientasi pada keuntungan. Pengelolaan sampah yang buruk tampak dari tidak dipisahnya sampah berdasarkan kategorinya (sampah organik, anorganik, maupun sampah B3), dan pengangkutan sampah yang tidak berakhir di TPA. Kurangnya kesadaran masyarakat akan bahaya sampah tampak dari enggannya masyarakat mengurangi penggunaan plastik dalam kehidupan sehari-hari. Kurangnya tanggung jawab produsen produk plastik tampak dari pembuangan limbah pabrik plastik secara sembarangan dan terus diproduksinya produk plastik tanpa memenuhi analisis dampak lingkungan (amdal).

Plastik berbahaya bagi kesehatan tubuh dan ekosistem lingkungan. Beberapa bahaya yang dapat ditimbulkan plastik bagi kesehatan tubuh adalah :

1. Menyebabkan Kanker

Plastik dapat berbahaya bagi kesehatan tubuh bahkan bisa menyebabkan kanker jika sampai terurai ke dalam tubuh. Hal ini dikarenakan plastik mengalami penguraian sebagai dioksin. Umumnya plastik terurai dalam tubuh melalui penggunaan alat-alat makan yang terbuat dari plastik, dapat juga terhirup ketika membakar sampah plastik.

2. Menganggu Sistem Saraf

Plastik yang telah terurai sebagai dioksin dan terhirup manusia bukan hanya dapat menyebabkan kanker, namun dapat juga menyebabkan kerusakan sistem saraf. Kerusakan sistem saraf ini juga akan berimbas pada kinerja organ dalam lainnya, karena pembakaran plastik yang tidak sempurna.

3. Pembekakan Hati

Kemasan plastik yang di pakai untuk membungkus makanan atau minuman panas juga dapat menimbulkan pembekakan hati.

4. Gangguan Reproduksi

Salah satu bahaya penggunaan plastik adalah gangguan reproduksi, hal ini disebabkan adanya bahan kimia tambahan yang beragam.

5. Radang Paru-Paru

Zat karsinogenik yang keluar dari pengunaaan botol atau plastik saat terkena paparan panas akan menyebabkan peradangan pada paru - paru.

6. Depresi

Depresi berawal dari stres yang sudah parah. Biasanya disebabkan oleh masalah internal maupun eksternal yang kemudian depresi berujung pada gangguan jiwa dan 
mental. Namun potensi depresi ini juga dapat disebabkan oleh paparan senyawa dari plastik saat proses pembakaran yang tidak sempurna.

Plastik juga berbahaya bagi ekosistem lingkungan, yaitu :

1. Mengakibatkan Banjir

Plastik dapat menyebabkan banjir bila pembuangannya tidak pada tempatnya. Plastik dapat menyumbat aliran sungai karena tidak mudah terurai dan akhirnya menumpuk.

2. Menurunkan Kesuburan Tanah

Plastik yang sulit/lama terurai menurunkan kesuburan tanah karena sirkulasi udara dalam tanah menjadi terhalang, ruang gerak makhluk bawah tanah yang dapat menyuburkan tanah pun menjadi terhambat dan tergangggu.

3. Menjerat Hewan

Bukan hanya hewan yang berada di dalam tanah, hewan yang berada di laut pun mengalami dampak negatif dari sampah plastik. Sampah plastik yang di buang ke perairan sungai atau laut menyebabkan hewan-hewan terjerat plastik.

4. Meracuni Makhluk Hidup

Hewan yang mati karena mengkonsumsi plastik, plastik yang ada dalam tubuh hewan tersebut tidak mudah terurai atau hancur. Ketika hewan tersebut menjadi bangkai, plastik dalam tubuhnya tetap ada dan tidak hancur, hal ini menyebabkan racun menyebar kepada makhluk hidup lainnya.

\section{Pencemaraan Air}

Plastik dapat memperburuk kualitas air, bahan kimia yang penuh racun seperti Bisphenol A, Styrene Trimer serta Polystyrene dapat mencemari air. Air tercemar yang digunakan untuk aktifitas sehari-hari dapat memepengaruhi kesehatan tubuh manusia.

\section{Polusi udara}

Membakar sampah menjadi cara yang banyak dipakai masyarakat untuk membuang sampah. Proses pembakaran ini akan mengkontaminasi atmosfer karena ketika sampah plastik di bakar, bahan kimia yang menjadi racun akan menyebar ke udara dan menyebabkan polusi udara.

Pemerintah sudah melakukan beberapa upaya untuk mengurangi limbah plastik di Indonesia. Beberapa upaya tersebut adalah mengeluarkan kebijakan uji coba mengurangi limbah plastik dengan cara mengenakan biaya dua ratus rupiah bagi konsumen yang ingin menggunakan kantong plastik. Pemerintah bekerjasama dengan berbagai swalayan untuk melancarkan program kerja ini. Program ini tidak berjalan mulus karena muncul banyak perdebatan di kalangan retail dan akhirnya pemerintah kembali menggratiskan kantong plastik. Pemerintah juga telah menggandeng World Economic Forum (WEF) dan menggalakkan program Indonesia bebas plastik dengan cara mengurangi sampah sebesar $70 \%$ ditahun 2020.

Presiden bahkan mengeluarkan Perpres Nomor 83 Tahun 2018 tentang penanganan sampah laut. Pasal 2 poin 1 menyebutkan dalam rangka penanganan sampah laut perlu ditetapkan strategi, program, dan kegiatan yang strategis, terukur, dan terarah untuk mengurangi jumlah sampah di laut, terutama sampah plastik dalam bentuk Rencana Aksi 
Nasional Penanganan Sampah Laut Tahun 2018-2025. Pasal 2 poin 3 menyebutkan Rencana Aksi dilaksanakan melalui strategi meliputi :

1. Gerakan nasional peningkatan kesadaran para pemangku kebijakan

2. Pengelolaan sampah yang bersumber dari darat

3. Penanggulangan sampah pesisir dan laut

4. Mekanisme pendanaan, penguatan, kelembagaan, pengawasan, dan penegakan hukum

5. Penelitian dan pengembangan

Berbagai upaya yang telah dilakukan pemerintah tidak akan ada artinya tanpa kesadaran masyarakat Indonesia untuk mengurangi sampah plastik. Setiap orang di Indonesia harus mengurangi sampah plastik. Menurut Endah (2015:18), upaya yang dapat dilakukan untuk mengurangi sampah plastik adalah melalui Reduce (mengurangi) yakni mengurangi barang yang digunakan, Reuse (penggunaan kembali) yakni menggunakan kembali barang-barang yang bisa digunakan, Recycle (mendaur ulang) yakni mendaur ulang barang-barang yang sudah tidak berguna menjadi sesuatu yang lebih bermanfaat, Replace (menggantikan) Mengganti barang-barang yang hanya dipakai sekali dengan barang yang lebih ramah lingkungan.

Mengingat urgensi penanganan sampah plastik di Indonesia, kami selaku Dosen Universitas Indraprasta PGRI merasa bertanggung jawab dan perlu melakukan upaya yang dapat membantu pemerintah dalam meningkatkan kesadaran masyarakat akan bahaya sampah plastik. Upaya tersebut kami lakukan melalui Pengabdian Kepada Masyarakat di Sekolah Paket B dan C UPT Pasar Sukatani, Depok. Adapun bentuk pengabdian masyarakat yang kami lakukan adalah dengan memberikan pelatihan pembuatan kriya pot lukis dari limbah botol plastik bekas.

Sekolah Paket B dan C UPT Pasar Sukatani merupakan hasil kerjasama antara Unit Pelaksana Teknis (UPT) Sanggar Kegiatan Belajar (SKB) Dinas Pendidikan (Disdik) Kota Depok yang berlokasi di Jl. Bunga 3 Blok B5 No.12, Sukatani, Tapos, Kota Depok, Jawa Barat 16454. Sekolah Paket B dan C UPT Pasar Sukatani termasuk dalam pendidikan non formal setara SMP dan SMA. Pendidikan non formal adalah kegiatan yang sistematik yaitu kegiatan yang memiliki komponen, proses, dan tujuan program (Djuju Sudjana 2008:4). Peserta didik sekolah ini 17 orang yang terdiri dari pedagang, petugas kebersihan (pesapon), petugas retribusi, petugas tertib pasar,serta pendudukan setempat baik yang putus sekolah ataupun yang tidak lulus ujian Nasional.

Sekolah Paket B dan C UPT Pasar Sukatani Depok kami pilih sebagai lokasi pengabdian masyarakat karena sekolah ini dekat dengan masyarakat, ditandai dengan keberadaannya di tengah masyarakat, yakni di dalam Pasar Sukatani. Peserta didik sekolah ini juga berasal dari berbagai latar belakang yang berbeda. Keberadaannya yang dekat dengan masyarakat dan peserta didik yang berasal dari berbagai latar belakang ini diharapakan dapat meningkatkan efektifitas sosialisasi mengurangi limbah plastik yang akan kami berikan melalui pelatihan pembuatan kriya pot lukis dari botol plastik bekas.

Berdasarkan pengamatan dan survei yang dilakukan oleh kami tim Pengabdian Kepada Masyarakat Universitas Indraprasta PGRI, terdapat dua permasalahan mitra yakni :

1. Belum pernah dilakukannya sosialisasi mengurangi sampah plastik melalui pelatihan pembuatan kriya pot lukis dari botol plastik di Sekolah Paket B dan C UPT Pasar Sukatani Depok.

2. Minimnya tanaman hijau di lingkungan Sekolah Paket B dan C UPT Pasar Sukatani Depok. 
Melihat kondisi tersebut maka perlu diberikannya sosialisasi mengurangi sampah plastik melalui pelatihan pembuatan kriya pot lukis dari botol plastik bekas di Sekolah Paket B dan C UPT Pasar Sukatani Depok.

Tujuan pelatihan pembuatan kriya pot lukis dari botol plastik bekas ini adalah meningkatkan kesadaran peserta didik Sekolah Paket B dan C UPT Pasar Sukatani Depok, khususnya dan masyarakat luas umumnya akan pentingnya mengurangi sampah plastik mengingat bahaya dari sampah plastik yang begitu besar. Pelatihan ini juga bertujuan membantu program pemerintah dalam upaya mengurangi jumlah sampah plastik yang ada di Indonesia.

\section{METODE PELAKSANAAN}

Tujuan dari kegiatan abdimas ini adalah untuk memberikan pelatihan pembuatan kriya pot lukis dari botol plastik bekas sebagai sosialisasi mengurangi sampah plastik di Sekolah Paket B dan C UPT Pasar Sukatani Depok. Dengan pelatihan ini diharapkan kriya pot lukis dari botol plastik bekas dapat meningkatkan kesadaran peserta didik Sekolah Paket B dan C UPT Pasar Sukatani Depok untuk mengurangi sampah plastik dengan melakukan tindakan Recycle (mendaur ulang) yakni mendaur ulang barangbarang plastik yang sudah tidak berguna menjadi sesuatu yang lebih bermanfaat. Diharapkan pula peningkatan upaya penghijauan di lingkungan sekolah, pasar, dan tempat tinggal peserta didik dan masyarakat lingkungan sekitar.

Pengabdian masyarakat dilakukan dengan memberikan pelatihan pembuatan produk pot lukis cantik (gambar 1) dengan menggunakan bahan baku utama botol plastik bekas dan cat minyak (gambar 2). Materi juga diberikan terlebih dahulu kepada peserta didik Sekolah Paket B dan C UPT Pasar Sukatani Depok sebelum pelaksanaan pelatihan. Tujuan pemberian materi adalah agar peserta didik memahami dan menangkap tujuan dari pelaksanaan abdimas.

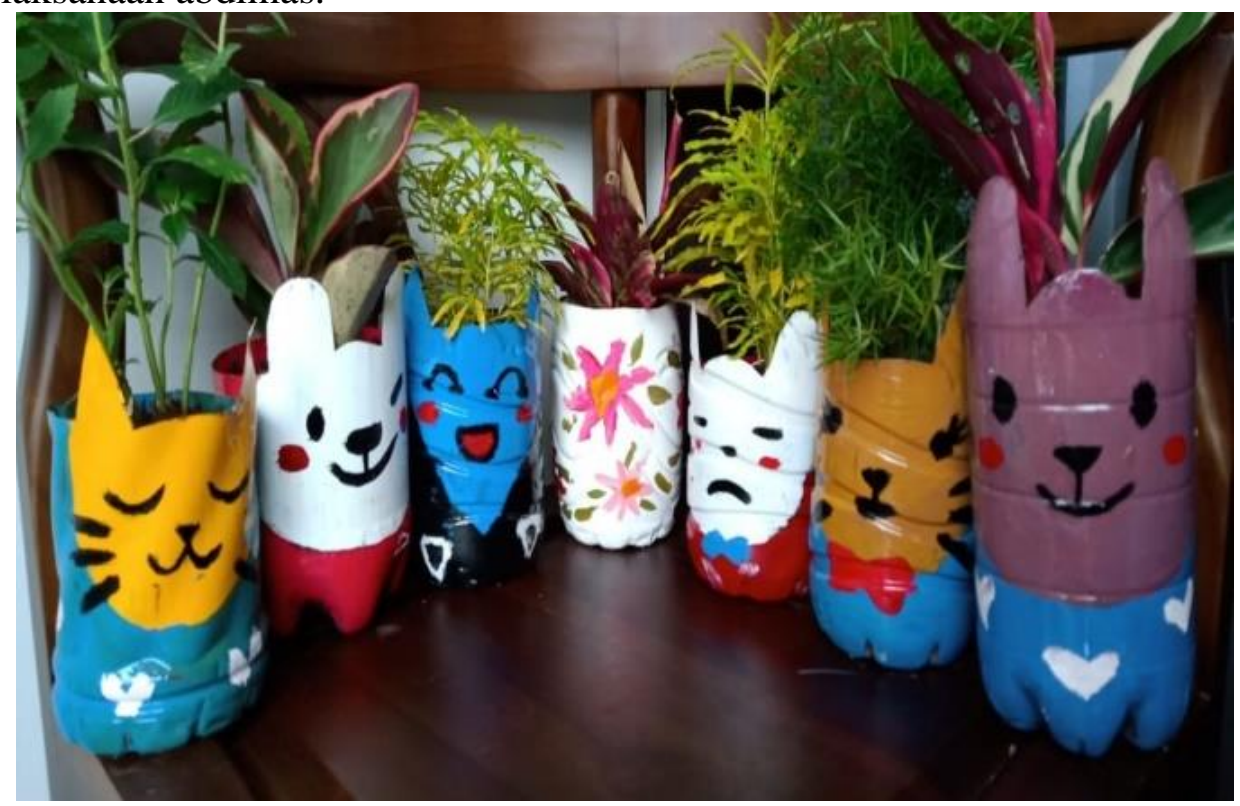

Gambar 1 Produk Pot Lukis dari Botol Bekas 


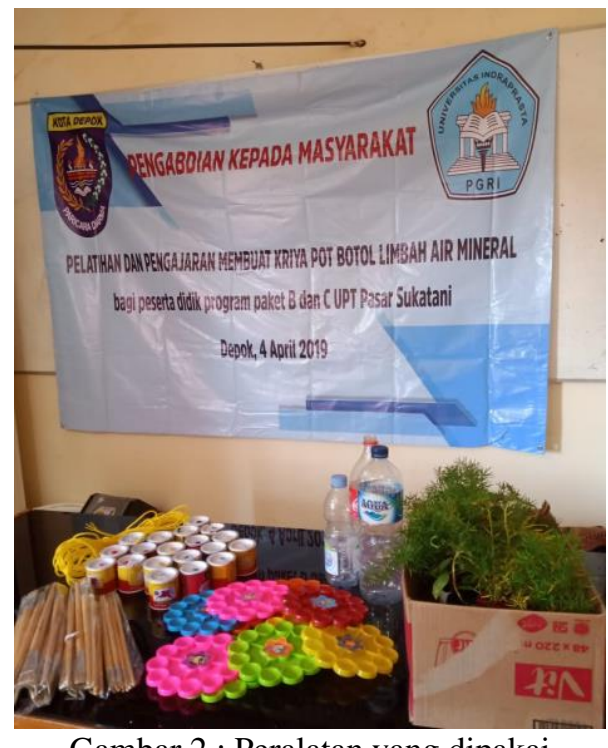

Gambar 2 : Peralatan yang dipakai

Metode yang dilaksanakan abdimas ini adalah pembelajaran yang berpusat dan berorientasi pada peserta didik (student centered learning). Metode ini diharapkan dapat meningkatkan antusiasme peserta didik dalam mengikuti pelatihan pembuatan kriya pot lukis. Meskipun berpusat pada peserta didik namun tim abdimas tetap memberikan arahan dan tutorial terlebih dahulu terkait pembuatan pot lukis. Selanjutnya peserta didik dapat mengkreasikan pot lukisnya masing-masing.

\section{HASIL DAN PEMBAHASAN}

Pelatihan abdimas pembuatan pot lukis dari botol plastik bekas diawali dengan memberikan penjelasan mengenai pentingnya memiliki kesadaran akan bahaya sampah plastik dan pentingnya penciptaan lingkungan hijau di lingkungan Sekolah Kejar Paket B dan C UPT Pasar Sukatani depok khususnya, dan lingkungan masyarakat umumnya. Berikut ini langkah-langkan dan teknik abdimas yang kami lakukan :

1. Penjelasan tentang pentingnya peningkatan kesadaran akan bahaya sampah plastik dan pentingnya penciptaan lingkungan hijau

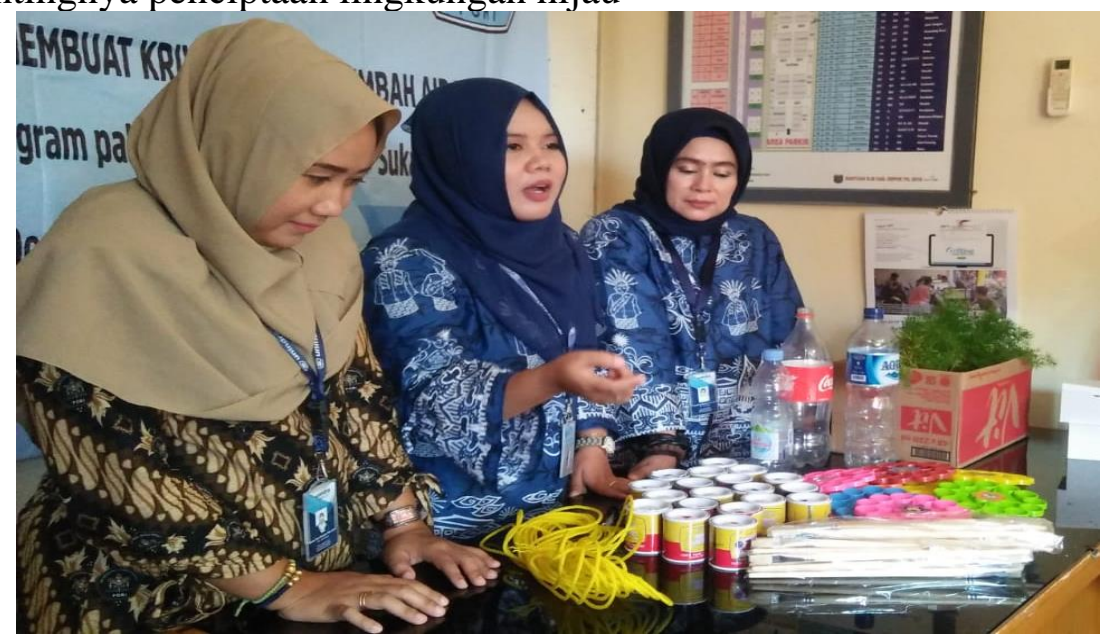

Gambar 3. Penjelasan materi tentang bahaya sampah plastik 
2. Penjelasan tambahan tentang High Order Thinking Skill, dimana pelatihan pembuatan pot plastik dapat menstimulasi peserta didik memiliki kemampuan berpikir tingkat tinggi.

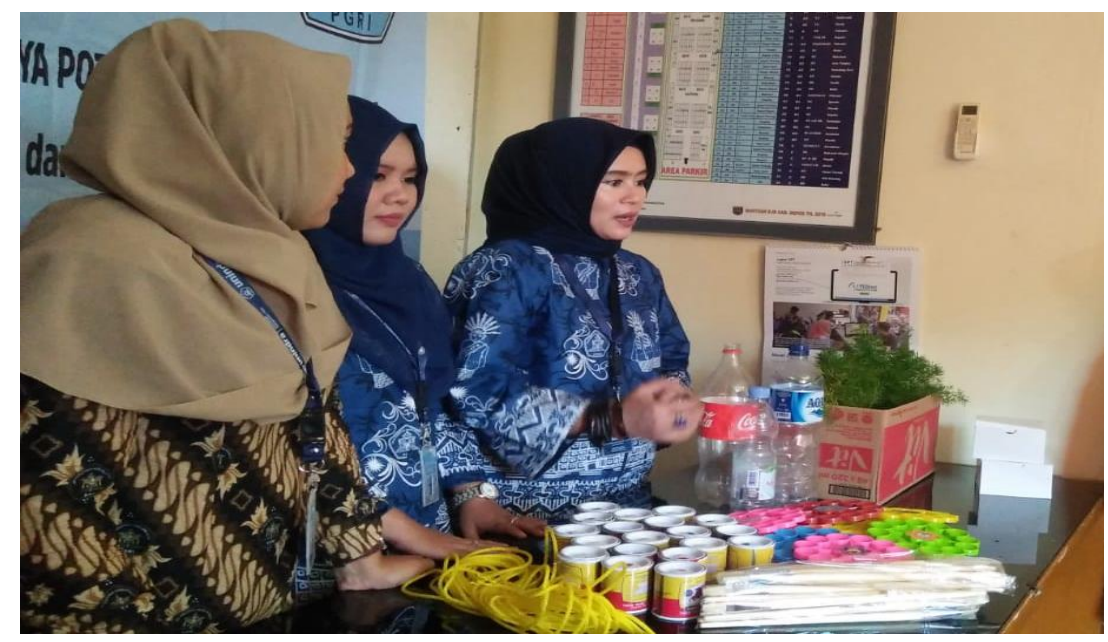

Gambar 4. Penjelasan materi tentang High Order Thinking Skill

3. Pemberian tutorial pembuatan pot lukis dari botol plastik bekas.

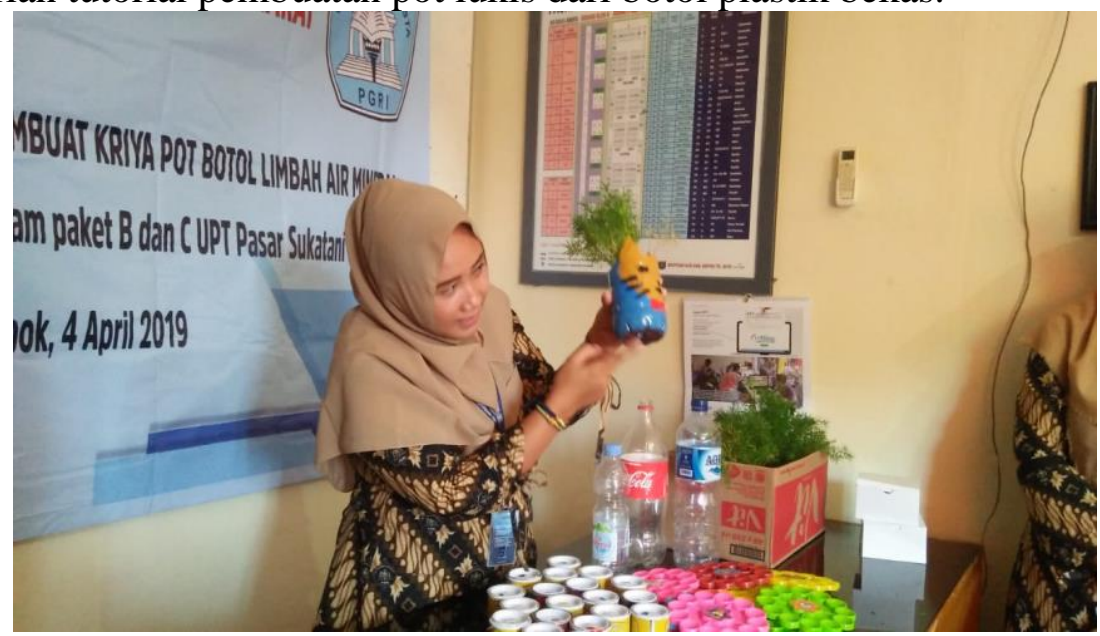

Gambar 5. Penjelasan cara membuat pot lukis dari botol beka

4. Pelatihan dan Praktek pembuatan pot lukis dari botol plastik bekas.

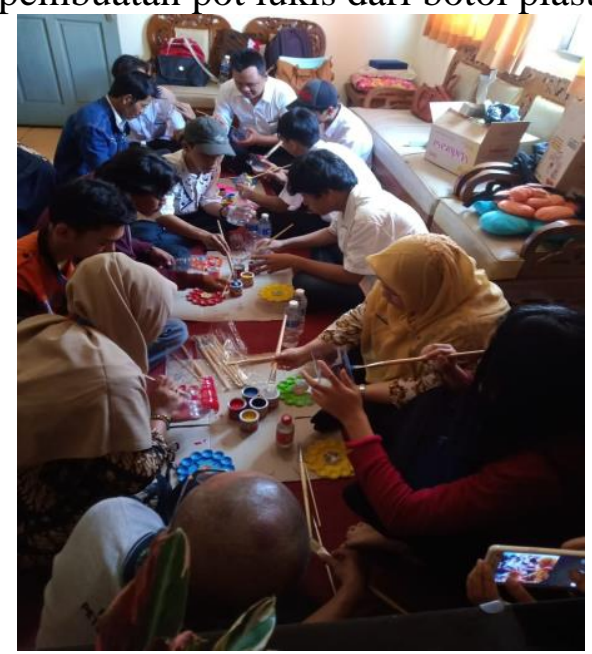

Gambar 6. Praktek pembuatan pot lukis 


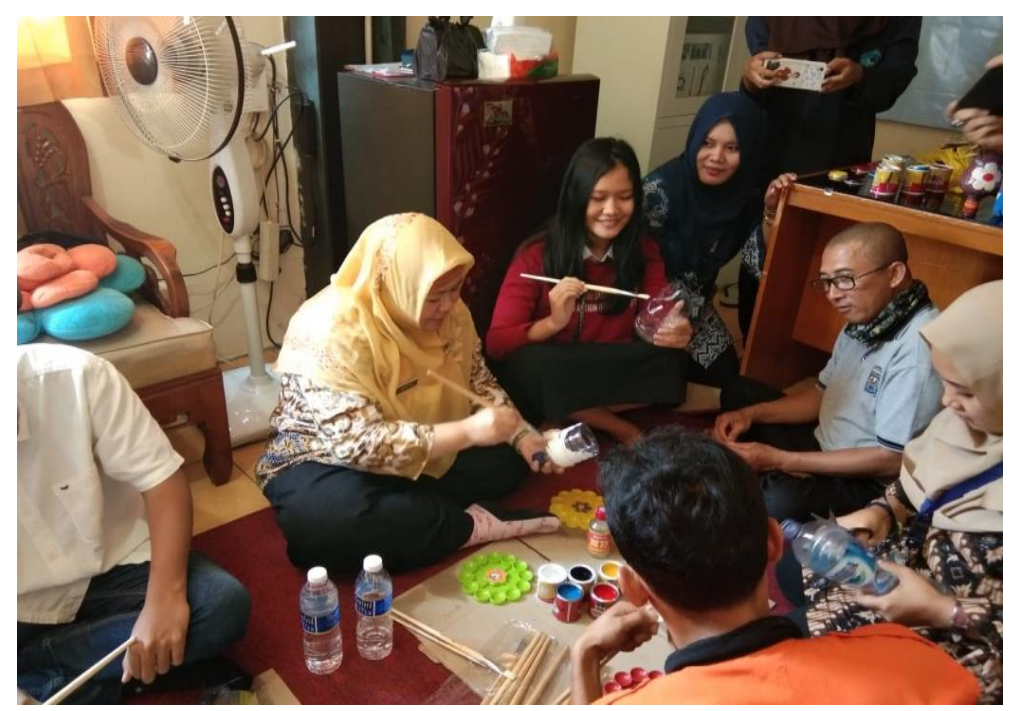

Gambar 7. Antusiasme peserta didik sekolah paket dalam membuat pot lukis

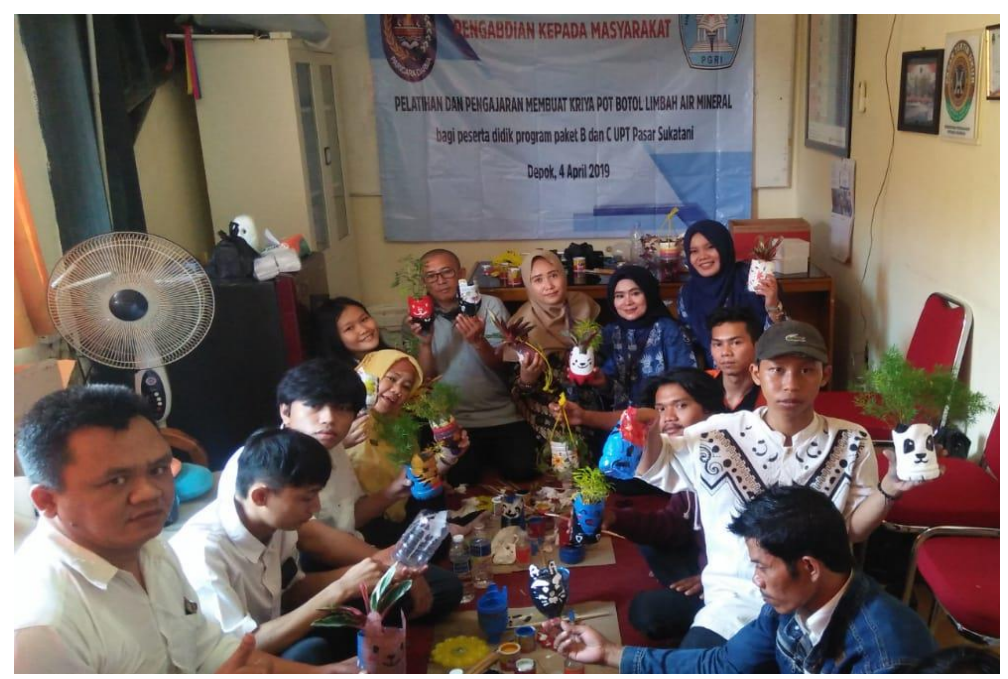

Gambar 8. Peserta abdimas menunjukan hasil karya pot lukis masing-masing

5. Penyerahan plakat kepada sanggar kelompok belajar di UPT Pasar Sukatani sebagai kenang-kenangan dan tanda terimakasih

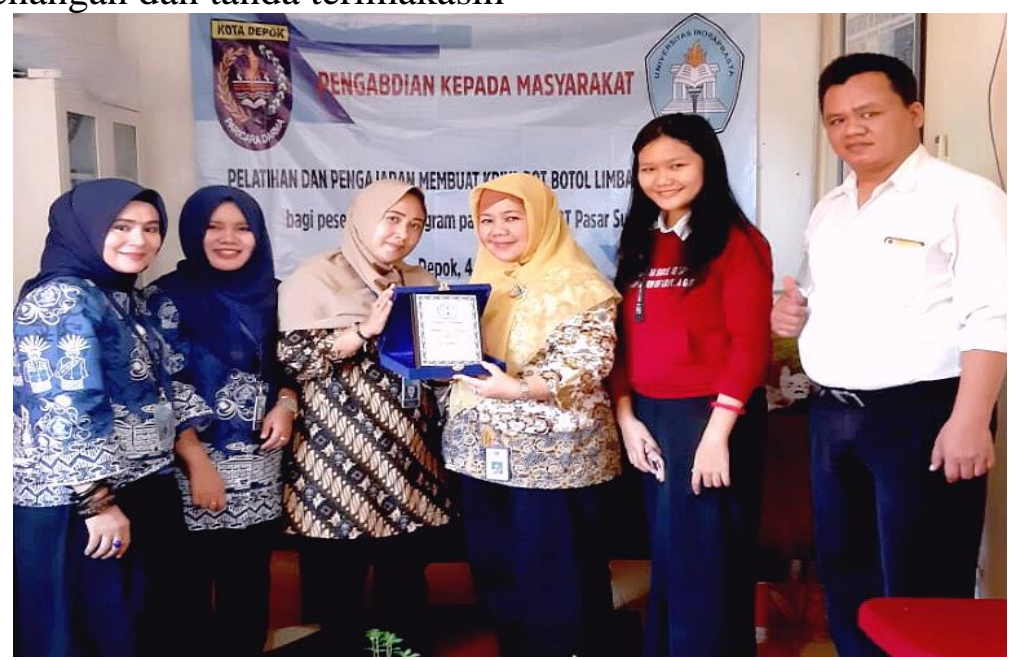

Gambar 9. Penyerahan plakat 
6. Penyerahan sertifikat kepada dosen unindra selaku pemateri

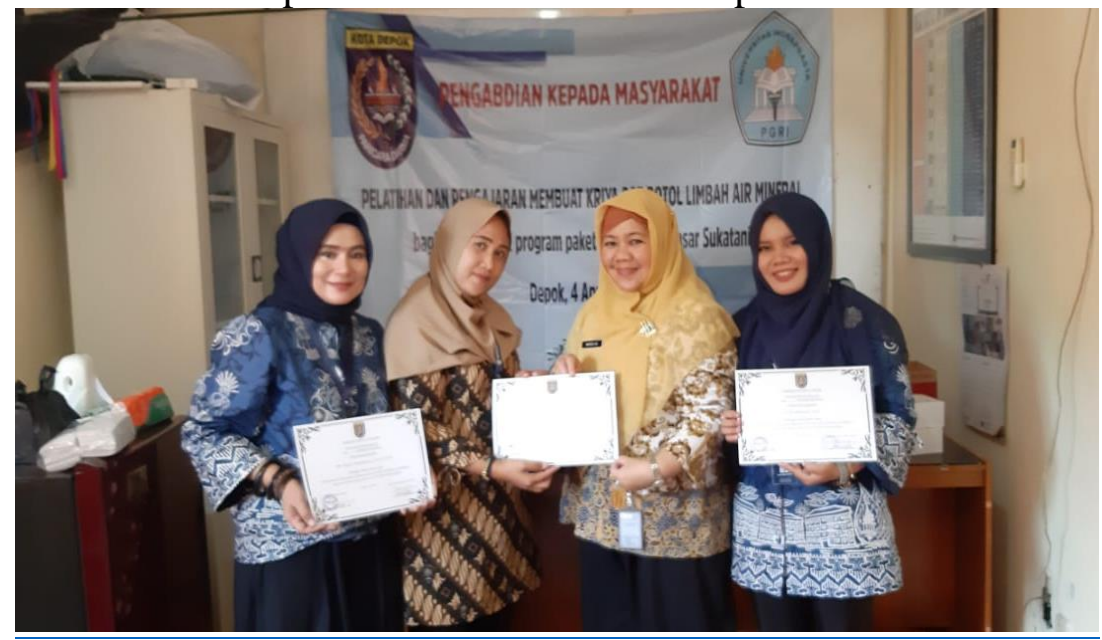

Gambar 10. Penyerahan sertifikat

Pengabdian Kepada Masyarakat Pelatihan Pembuatan Kriya Pot Lukis dari Botol Plastik Bekas di Sekolah Paket B dan C UPT Pasar Sukatani, memberikan simpulan bahwa kegiatan ini :

1. Pelatihan pembuatan kriya pot lukis dari botol plastik bekas sebagai sosialisasi kurangi sampah plastik berjalan dengan baik dan lancar. Peserta didik Sekolah Paket B Dan C UPT Pasar Sukatani begitu antusias memperhatikan materi yang diberikan dan mencoba praktik langsung membuat pot lukis dari botol plastik bekas.

2. Praktik langsung pembuatan pot lukis plastik sudah berjalan dengan baik dan lancar. Semua peserta didik membuat pot lukis plastik dengan memaksimalkan daya kreatifitas masing-masing.

3. Hasil praktik selanjutnya kami persilahkan untuk dipasang/diletakkan di tembok sekolah dan lingkungan sekitar Pasar Sukatani Depok, tujuannya untuk mengajak peserta didik dan masyarakat sekitar sadar akan bahaya sampah plastik, sadar akan pentingnya mengurangi sampah plastik dan melakukan penghijauan.

\section{SIMPULAN}

Berbagai upaya pemerintah mengurangi sampah plastik tidak akan berhasil tanpa adanya peran aktif seluruh komponen masyarakat. Tim abdimas Universitas Indraprasta PGRI berupaya memberikan solusi dengan meningkatkan kesadaran masyarakat tentang bahaya sampah plastik dan pentingnya kurangi sampah plastik melalui pelatihan pembuatan pot lukis dari botol plastik bekas. Pelatihan dilaksanakan di Sekolah Paket B dan C UPT Pasar Sukatani Depok. Keberadaan Sekolah Paket B dan C UPT Pasar Sukatani yang dekat dengan masyarakat dan peserta didik yang berasal dari berbagai latar belakang dapat meningkatkan efektifitas upaya peningkatan kesadaran akan bahaya sampah plastik, pentingnya mengurangi sampah plastik dan melakukan penghijauan.

\section{DAFTAR PUSTAKA}

Endah, R.A. (2015). Kreasi dari Limbah Plastik. Jakarta : Penebar Swadaya Grup. 
Jambeck, J. R., Geyer, R., Wilcox, C., Siegler, T. R., Perryman, M., Andrady, A., ... \& Law, K. L. (2015). Plastic waste inputs from land into the ocean. Science, 347(6223), 768-771. https://science.sciencemag.org/CONTENT/347/6223/768.abstract

Peraturan Presiden Republik Indonesia Nomor 83 Tahun 2018 Tentang Penanganan Sampah Laut.

Sudjana, D. (2008). Evaluasi Program Pendidikan Luar Sekolah. Bandung : PT. Remaja Rosdakarya. 